\title{
SABINE'S GULLS AT TURTLE LAKE, SASKATCHEWAN
}

RON JENSEN, 1027 King Crescent, Saskatoon, Saskatchewan. S7K 0N9.

To make preparations for the annual summer meeting, Stan Shadick and I joined Gary and Muriel Carlson at Turtle Lake for the June 4th weekend. Turtle Lake is a resort area about 100 $\mathrm{km}$ northwest of The Battlefords on the southern edge of the boreal forest.

Saturday we started early, looking for warblers, and spent the rest of the day visiting possible tour sites for the annual meeting. On a boat trip that evening to view the heronry and an osprey nest, we watched gulls rise in flight before the boat to alight in its wake. It was quite easy to identify the Bonaparte's and Franklin's Gulls by their distinctive wing patterns. Stan pointed out one gull with black outer primaries and distinctly forked white tail. Our combined resolve was a Sabine's Gull. It was, however, on our return trip to the Carlson's cabin that we found six Sabine's Gulls feeding in a loose flock of Bonaparte's and
Franklin's. Stan, Muriel and myself watched the gulls for 15 minutes concluding that these were Sabine's Gulls. This was a satisfying close to an enjoyable day, adding a new species to the list for the Turtle Lake area.

Sabine's Gull sightings for the three prairie provinces are considered rare by Godfrey. ${ }^{1}$ There are at least six articles of detailed sightings from southern Alberta, and Manitoba and Saskatchewan published in the Blue Jay from as early as $1914 .^{2}$

Although not a new bird for the prairies, the Sabine's Gull is not a yearly visitor - a pleasant reward for a birder's efforts.

1 GODFREY, W. E. 1966. The Birds of Canada. Nat. Mus. Can. Bull. 203.

2 COPLAND, H.W.R. 1969. A Sabine's Gull in southern Saskatchewan. Blue Jay 28:146-147.

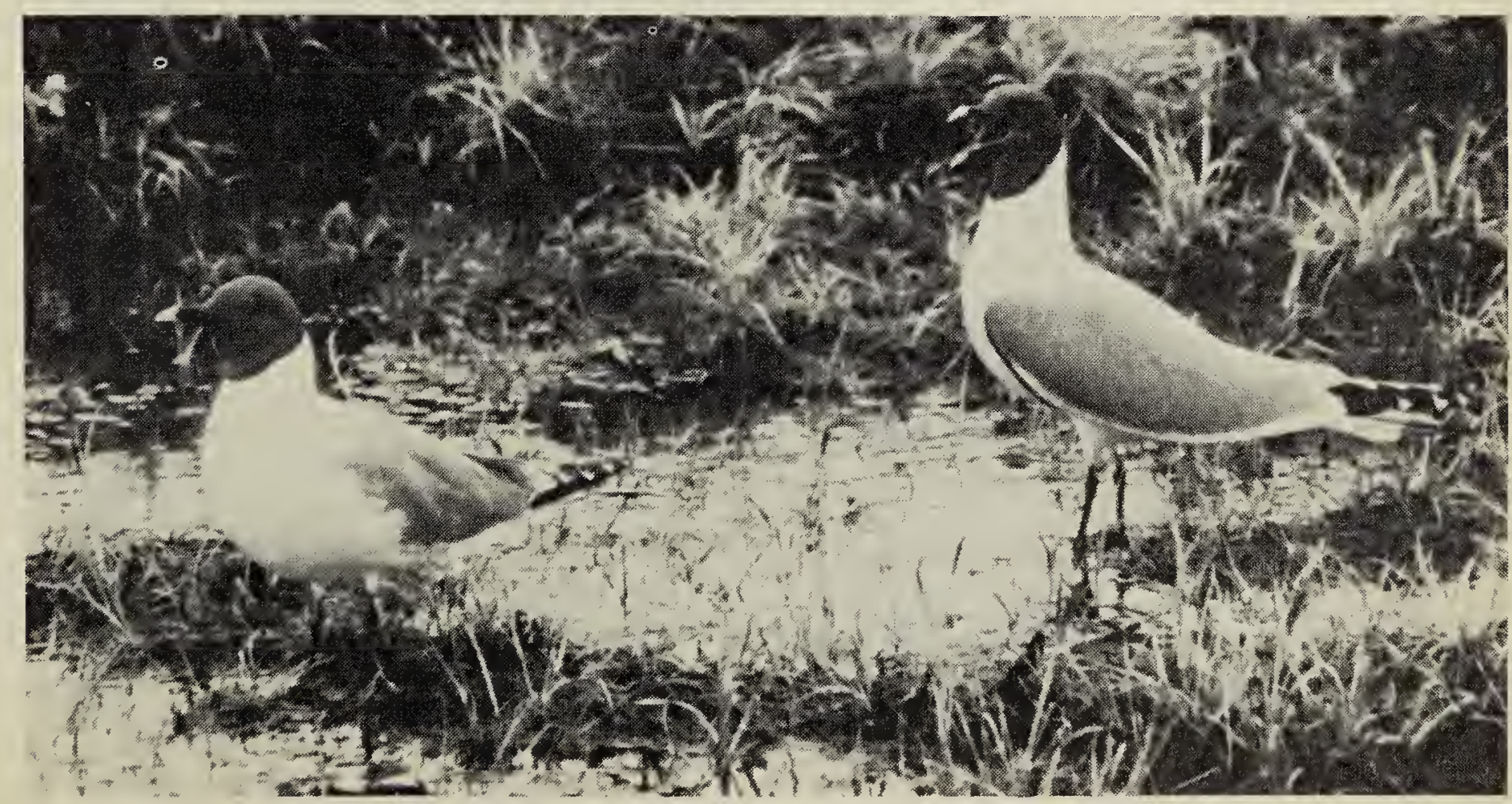

Sabine's Gulls, Cambridge Bay, N.W.T.

Stan Shadick 